\title{
The prevalence and risk factors of hand eczema among emergency healthcare workers during the COVID-19 pandemic
}

\author{
COVID-19 pandemisi süresince acil sağlık çalışanları arasındaki el egzaması \\ prevalansı ve risk faktörleri

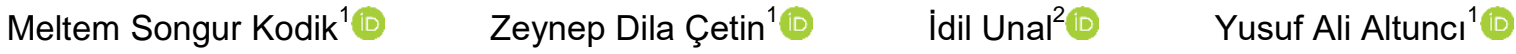 \\ ${ }^{1}$ Ege University Faculty of Medicine, Department of Emergency Medicine, Izmir, Turkey \\ ${ }^{2}$ Ege University Faculty of Medicine, Department of Dermathology, Izmir, Turkey
}

\begin{abstract}
Aim: The preventive measures to decelerate the spread of the novel coronavirus include intense hand sanitizing which is a risk factor for hand eczema. Occupational hand eczema is common among healthcare workers due to their exposure to wet work and chemical irritants. We aimed to evaluate the prevalence of hand eczema among healthcare workers currently working in the emergency department and investigate the alterations regarding the risk factors during the COVID-19 pandemic that began in March 2020 in Turkey.

Materials and Methods: An online survey was sent to healthcare workers in emergency departments all over Turkey. Participants were asked to evaluate their frequency of hand washing, hand eczema, glove use and moisturizer use as prior to and during the COVID-19 pandemic. Hand eczema and associated symptoms were self-reported.

Results: Three hundred fifty-four healthcare workers, consisting of 260 emergency physicians and 94 nurses returned the survey. The prevalence of HE among 354 participants with a median age of 32 was $48.6 \%(n=161)$. HE was associated with having an atopic history $(p<0.001) .54 .8 \%(n=194)$ of the participants reported having symptoms associated with HE prior to the pandemic and the rate increased significantly to $64.7 \%(n=229)$ during the pandemic $(p<0.001)$. The exposure to the risk factors of hand eczema such as hand washing frequency and duration of glove use showed a relevant increase during the pandemic $(p<0.001)$. As well as moisturizer applying frequency which also increased during the pandemic $(p<0.001)$.
\end{abstract}

Conclusion: With the outbreak of the COVID-19 pandemic, Healthcare workers intensified their hand hygiene practices as recommended and increased their risk for hand eczema.

Keywords: COVID-19, hand eczema, healthcare workers.

\section{ÖZ}

Amaç: Yeni koronavirüsün yayılma hızını yavaşlatmak amacıyla alınan önlemler arasında egzama risk faktörü olan yoğunlaştırılmış el dezenfeksiyonu bulunmakta. Sağlık çalışanlarının ıslak çalışma ve irritant kimyasallara maruziyetleri nedeniyle mesleki el egzaması oldukça yaygın. Bu çalışmamızda, acil servislerde çalışan sağlık çalışanları arasında var olan el egzaması prevalansını ortaya koyup, Türkiye'de Mart 2020'de başlayan COVID-19 pandemisi sürecinde risk faktörlerinde meydana gelen değişiklikleri irdelemeyi hedefledik.

Gereç ve Yöntem: Anketimizi Türkiye'deki acil servislerde çalışan sağlık çalışanlarına e-posta yoluyla ulaştııılı. Katılımcılardan el yıkama sıklıklarını, eldiven kullanım sürelerini, el nemlendiricisi kullanım sıklıklarını pandemi öncesi ve süresince olarak değerlendirmeleri istendi. El egzamasının ve ilişkili semptomların varlığı kişisel beyana dayandırıldı.

\footnotetext{
Corresponding author: Meltem Songur Kodik

Ege University Faculty of Medicine, Department of

Emergency Medicine, Izmir, Turkey

E-mail: songurm@yahoo.com

Application date: 28.04.2021

Accepted: 20.05.2021
} 
Bulgular: Anketimizi cevaplayan 354 sağlık çalışanından 260'ı hekim, 94'ü hemşireydi.

Ortalama yaşın 32 olduğu örneklemimizde 48,6\% (n=161) el egzaması görüldü ve atopik bir hikâyeye sahip olmak ile ilişkilendirildi $(p<0,001)$. El egzamasıla ilişkili semptomların görülme oranı pandemi öncesinde 54,8\% (n=194) iken pandemi sürecinde 64,7\% (n=229) olarak anlamlı bir artış gösterdi $(p<0,001)$. Egzama risk faktörlerine maruziyeti el yıkama sıklığı ve eldiven kullanım süresini irdeleyerek ikisinde de anlamlı bir artış gözlemledik $(p<0,001)$. Aynı zamanda sağlık çalışanları pandemi süresince ellerini daha sık nemlendirme ihtiyacı duyduklarını belirtti $(p<0,001)$.

Sonuç: COVID-19 pandemisinin ortaya çıkmasıyla sağlık çalışanlarının uyması gereken el hijyen protokolleri yoğunlaştırıldı, bunun sonucunda sağlık çalışanlarında el egzaması oluşma riski arttı.

Anahtar Sözcükler: COVID-19, el egzaması, sağlık çalışanı.

\section{INTRODUCTION}

The coronavirus disease (COVID-19) is caused by severe acute respiratory syndrome coronavirus 2 (SARS-CoV2), which has led to a severe pandemic since its outbreak in Wuhan, China in December 2019. The virus can be transmitted directly by droplet or indirectly by contaminated surfaces (1). In order to reduce its spreading through contaminated surfaces the World Health Organization (WHO) recommended to disinfect the hands regularly by washing them with soap and water or by using an alcohol-based hand sanitizer containing at least $70 \%$ of alcohol (2). Even though frequent hand sanitizing decreases the transmission of the virus, it also increases the risk of developing contact dermatitis by damaging the skin barrier (3).

Health care workers (HCWs) are a population susceptible to develop occupational skin diseases such as irritant contact dermatitis and allergic contact dermatitis because of their exposure to wet work including frequent hand washing (HW) with soap and water, occlusive gloves and irritant chemicals for instance alcoholbased disinfectants $(4,5)$.

Recent studies have shown a significant increase in HW frequency and high prevalence of selfreported hand eczema (HE) among HCWs during the ongoing pandemic $(6,7)$. The increase in HW frequency and a high prevalence of HE was seen in both HCWs attending to COVID-19 patients and those without direct contact with the COVID19 patients, no significant difference was found between these two groups (7).

This study aims to evaluate the prevalence of hand eczema (HE) in HCWs working in the emergency departments (ED) all over Turkey and to determine if there has been a change in their hand sanitizing frequencies, glove use and choice of disinfectant product during the COVID19 pandemic.

\section{MATERIALS and METHODS \\ Questionnaire Design}

The questionnaire used to collect data was modified from the long version of the Nordic Occupational Skin Questionnaire-2002 (NOSQ2002) by the authors (8). It was designed as an online questionnaire and included questions on demographics and occupational history, atopic history, self-reported hand eczema, exacerbating factors, skin symptoms, skin tests and exposure. The questions regarding the frequency of hand eczema, hand washing, glove use and moisturizer apply, the presence of skin symptoms and the choice of the hand sanitizing product were asked as prior to and during the COVID-19 pandemic.

\section{Data Collection}

This study was approved by the ethics committee of medical research of Ege University, İzmir on 15.02.2021 (no: 21-2T/39). The online questionnaire link was sent by e-mail to all the HCWs working in the ED during the 4 weeks of data collection. Participants were informed about the study's purpose and the use of their data. Before they could proceed with the questions, they were asked to give consent and confirm they were currently working in the emergency clinic. We collected data between 19.02.202122.03.2021 and reached a total of 354 participants consisting of medical staff (physicians, nurses) working in the emergency departments in Turkey.

\section{Variables}

The main dependent variable in this study was the presence of eczema. The participants who answered, 'yes' to the question 'Have you ever 
had hand eczema?' or pointed having symptoms related to eczema were acceded.

The independent variables of the study were: sociodemographic characteristics (sex, age, profession, workplace), atopic history (the participants who indicated having any of the four atopy related symptoms asked in the questionnaire were accepted as atopic), hand washing frequency, product choice for hand sanitizing (soap and water, alcohol-based hand sanitizer), glove use frequency (determined by hours per week), glove types (latex, vinyl, nitryl) and use of moisturizer (times per day).

\section{Statistical Analysis}

Statistical analysis was performed by a professional statistician using the Statistical Package for Social Sciences program (IBM SPSS Statistics for Windows, Version 25.0. Armonk, NY: IBM Corp.). The level of significance for all the analysis was determined as $p=0.05$. Descriptive data statistics were presented as mean, standard deviation, median, minimum, maximum, frequency and percentage. The compatibility of the numeric data to normal distribution was evaluated with the Shapiro-Wilk test. The variables with a normal distribution were compared with independent samples t-test while Wilcoxon signed ranks test was used to compare variables that were not compatible with normal distribution. Pearson Chi-square and Mc-Nemar tests were used to compare categorical variables.

\section{RESULTS}

\section{Sociodemographic}

Three hundred fifty-four HCWs with a median age of 32 years, answered the questionnaire (260 physicians, 94 nurses) and $48.6 \% \quad(n=172)$ of them reported having $\mathrm{HE}$ at one point in their life. No significant correlations were found between the participants with self-reported HE (SRHE) and those without SRHE in regards of sex, median age, profession or weekly working hours. On the other hand, $87.2 \%$ (150 of 172) of the participants with SRHE had an atopic history, which was found significant $(p<0.001)$. The sociodemographic characteristics for the participants with and without SRHE are shown in (Table-1).

\section{Symptoms}

Two hundred and twenty-nine participants reported having at least one of the HE associated symptoms (HEAS) during this last year and $21 \%$ (48 of 229) of them did not have any symptoms prior to the COVID-19 pandemic. All the HEAS showed a significant increase during the pandemic $(p<0.001)$ except for vesicles and papules. Erythema, scaling/flaking and itching were the three most common symptoms among HCWs both prior to and during the COVID-19 pandemic. The HEAS prevalence before and during the COVID-19 pandemic is shown in (Table-2).

Table-1. Characteristic comparison between self-reported hand eczema group and non-self-reported hand eczema group.

\begin{tabular}{llccccc}
\hline & & Yes & SRHE & No & & p-value \\
\hline \multirow{3}{*}{ Total } & & $\mathrm{n}$ & $\%$ & $\mathrm{n}$ & $\%$ & \\
& & 161 & 45.5 & 193 & 54.5 & \\
Sex & Male & 64 & 18.1 & 86 & 24.3 & \\
Profession & Female & 97 & 27.5 & 107 & 30.2 & 0.404 \\
& Physician & 119 & 33.6 & 141 & 39.8 & 0.871 \\
History of Atopy & Nurse & 42 & 11.9 & 52 & 14.7 & \\
& Yes & 150 & 42.4 & 107 & 30.2 & $<0.001$ \\
& No & 22 & 6.2 & 75 & 21.2 & \\
Age & & Median & Min-max & Median & Min-max & \\
Weekly Working Hours & & 33 & $21-56$ & 31 & $22-68$ & 0.632 \\
\hline
\end{tabular}

SRHE: Self-reported hand eczema 
Table-2. Hand eczema associated symptoms before and during the pandemic.

\begin{tabular}{|c|c|c|c|c|c|}
\hline & $\begin{array}{l}\text { Before the } \\
\text { pandemic }\end{array}$ & & $\begin{array}{l}\text { During the } \\
\text { pandemic }\end{array}$ & & $\mathrm{p}$-value \\
\hline & $\mathrm{n}$ & $\%$ & $\mathrm{n}$ & $\%$ & \\
\hline HEAS & 194 & 54.8 & 229 & 64.7 & $<0.001$ \\
\hline Erythema & 134 & 37.9 & 184 & 52 & \\
\hline Scaling/Flaking & 122 & 34.5 & 158 & 44.5 & \\
\hline Itching & 126 & 35.6 & 155 & 43.8 & \\
\hline Tenderness & 102 & 28.8 & 151 & 42.7 & \\
\hline Fissure/Cracks & 89 & 25.1 & 128 & 36.2 & \\
\hline Burning/Stinging & 70 & 19.8 & 128 & 36.2 & \\
\hline Aching/Pain & 64 & 18.1 & 101 & 28.5 & \\
\hline Urticaria & 53 & 15 & 85 & 24 & \\
\hline Crust & 46 & 13 & 71 & 20.1 & \\
\hline Vesicle & 14 & 4 & 18 & 5.1 & 0.289 \\
\hline Papule & 10 & 2.8 & 13 & 3.7 & 0.549 \\
\hline
\end{tabular}

HEAS: Hand eczema associated symptoms.

Table-3. Hand washing frequencies before and during the pandemic.

\begin{tabular}{|c|c|c|c|c|c|c|}
\hline & & $\begin{array}{l}\text { Before the } \\
\text { Pandemic }\end{array}$ & & $\begin{array}{l}\text { During the } \\
\text { Pandemic }\end{array}$ & & p-value \\
\hline & & $\mathrm{n}$ & $\%$ & $\mathrm{n}$ & $\%$ & \\
\hline \multirow[t]{4}{*}{$\mathrm{HW}$ frequency groups } & $0-5$ & 80 & 22.6 & 5 & 1.4 & $<0.001$ \\
\hline & $6-10$ & 134 & 37.9 & 36 & 10.2 & \\
\hline & $11-20$ & 88 & 24 & 129 & 36.4 & \\
\hline & $20<$ & 55 & 15.5 & 184 & 52 & \\
\hline
\end{tabular}

HW: Hand washing

Table-4. Exposure to risk factors and prevention of hand eczema before and during the pandemic.

\begin{tabular}{|c|c|c|c|c|c|c|}
\hline & & $\begin{array}{l}\text { Before the } \\
\text { Pandemic }\end{array}$ & & $\begin{array}{l}\text { During the } \\
\text { Pandemic }\end{array}$ & & p-value \\
\hline & & Median & Min-max & Median & $\begin{array}{l}\text { Min- } \\
\max \end{array}$ & \\
\hline Duration of Glove use (hours) & & 3 & $0-24$ & 5.7 & $0-30$ & $<0.001$ \\
\hline \multirow[t]{2}{*}{ Moisturizer use (time per day) } & & 1 & $0-20$ & 3 & $0-30$ & \\
\hline & & $\mathrm{n}$ & $\%$ & $\mathrm{n}$ & $\%$ & \\
\hline \multirow[t]{2}{*}{ Product used for hand sanitation } & Soap & 323 & 91.2 & 316 & 83.9 & 0.419 \\
\hline & $\mathrm{ABHS}$ & 128 & 34.2 & 292 & 82.5 & $<0.001$ \\
\hline
\end{tabular}

ABHS: Alcohol-based hand sanitizer 
Table-5. Hand eczema frequencies before and during the pandemic.

\begin{tabular}{|c|c|c|c|c|c|c|}
\hline & & \multirow{2}{*}{$\begin{array}{c}\text { Before the } \\
\text { Pandemic } \\
n\end{array}$} & \multicolumn{3}{|c|}{$\begin{array}{l}\text { During the } \\
\text { Pandemic }\end{array}$} & \multirow[t]{2}{*}{ p-value } \\
\hline & & & $\%$ & $\mathrm{n}$ & $\%$ & \\
\hline \multirow{4}{*}{$\begin{array}{l}\text { HE frequency } \\
\text { groups }\end{array}$} & Only once and for less than two weeks & 108 & 56.5 & 56 & 29.3 & $<0.001$ \\
\hline & Only once but for two weeks or more & 13 & 6.8 & 21 & 11 & \\
\hline & More than once & 61 & 31.9 & 62 & 32.5 & \\
\hline & (nearly) All the time & 9 & 4.7 & 52 & 27.2 & \\
\hline
\end{tabular}

HE: Hand eczema

\section{Exposures}

During the pandemic, hand washing frequency increased significantly $(p<0.001)$, our data showed that every participant either increased or did not change their hand washing frequency. While the majority (37.9\%) used to wash their hands 6-11 times a day, more than half of the participants declared washing their hands more than 20 times per day during the pandemic (Table-3).

The question regarding the protective gloves was answered by $73.4 \% \quad(n=260)$ of the participants and revealed a significant increase in the duration of daily glove use during the pandemic. Latex gloves were the most used among the three types of gloves both before and during the COVID-19 pandemic. Whereas 180 participants indicated having HEAS because of latex gloves. On the other hand, a significant increase in the prevalence of HCWs using vinyl gloves occurred during the pandemic $(p<0.001)$. 180 participants indicated having HEAS because of latex gloves.

The response rate for moisturizer use was $45.5 \%$ $(n=161)$. Moisturizer applying frequency showed a significant increase $(p<0.001)$. HCWs used to apply hand moisturizer on average 1 time per day but with the beginning of the COVID-19 pandemic they started applying 3 times a day. Products chosen to disinfect the hands were either alcohol-based hand sanitizers (ABHS) or washing the hands with soap and water. The latest not being relevant as to prior or during the pandemic, ABHS usage increased significantly during the pandemic $(p<0.001)$. The results are shown in (Table-4).

Among 354 participants, 53.9\% $\quad(n=191)$ answered the question about the frequency of their eczema. More than half of them declared having had eczema only once and for less than two weeks prior to the pandemic. With the outbreak of COVID-19, the frequencies increased significantly (Table-5).

\section{DISCUSSION}

Since the first COVID-19 case submerged in December 2019, first the Chinese and then the whole world adapted to new circumstances. One of the challenges the HCWs had to overcome was attending to COVID-19 patients wearing personal protective equipment during long hours, which caused them discomfort on many levels. In this study conducted among HCWs currently working in the Emergency department (ED), the presence of an atopic history was significantly higher among HCWs who had HE. On the other hand, gender, age, profession or weekly working hours were not significantly different among the HCWs with HE and the HCWs without HE. When compared between prior to and during the pandemic, there was a significant increase in hand washing, glove use, use of moisturizers as well as $\mathrm{HE}$ frequency and the prevalence of HEAS.

Various research focused on the pandemic's effects on HCWs, a lot of which concern the front line where they attend to COVID-19 patients $(7,9,10)$. The first studies among front line HCWs showed a high prevalence in skin damages due to enhanced infection-prevention measures with hands being the third most affected site (9). Later on, Guertler et al. conducted a study, which showed a high prevalence in HE regardless of having direct contact with COVID-19 patients (7). In a study among $564 \mathrm{HCWs,} \mathrm{Celik} \mathrm{et} \mathrm{al.}$ reported $\mathrm{HE}$ related symptoms being significantly higher in women and in participants with an atopic history (11). Our study focused on HCWs 
currently working in the ED, which may or may not involve direct contact with COVID-19 patients since we do not perform a PCR test or a CT scan if it is not necessary.

On the other hand, Lan et al. performed a study among front line HCWs and found an HE prevalence of $70.3 \%$ (9). Hence, in another study by Guertler et al., the prevalence of self-reported HE was $14.9 \%$ and HE associated symptoms were $90.4 \%(7)$. In a study where the diagnosis was made by a dermatologist through physical examination, Erdem et al. found an $\mathrm{HE}$ prevalence of $50.5 \%$ (12). All these studies showed the prevalence of HE or HE associated symptoms during the pandemic of COVID-19. Although, Celik et al. presented new data on $\mathrm{HE}$ and $\mathrm{HE}$ associated symptoms and compared them as to prior and during the pandemic allowing to see if any changes had occurred. They found a significant increase in both, selfreported $\mathrm{HE}$ went from $6.6 \%$ to $11.7 \%$ and $\mathrm{HE}$ associated symptoms from $39.5 \%$ to $79.3 \%$ (11). In some studies, the most common three HE associated symptoms were dryness, erythema and itching $(7,11)$. Our study supported the increase in HEAS prevalence during the COVID19 pandemic even though more than half of the participants already had at least one HEAS prior to the COVID-19 pandemic, which shows an existing high prevalence in HE among HCWs. Additionally, we found that the three most common $\mathrm{HE}$ associated symptoms were erythema, itching, scaling/flaking and during the COVID-19 pandemic, there was a significant increase in the prevalence of all the symptoms except vesicle and papules.

Hand eczema has been an inconvenience for HCWs way before the COVID-19 pandemic. Various studies pointed to a higher prevalence of HE among HCWs compared to general public $(4,5)$, therefore leading to research to understand the cause, which was associated with wet work such as frequent hand washing, wearing occlusive gloves and exposure to irritant chemicals including alcohol-based disinfectants (4). Following the outbreak of COVID-19, WHO indicated that frequent hand sanitizing was important in order to prevent the spread of SARS-CoV-2 (2). Several studies indicated a high frequency in hand washing during the COVID-19 pandemic and it was associated with the risk of $\mathrm{HE}(7,9,11,12)$. Furthermore, Guertler et al. compared the hand washing frequencies among HCWs as prior to and during the COVID19 pandemic indicating a highly significant increase in HW during the pandemic (7). Our study revealed that not only HW frequency but also, HE frequency increased significantly among HCWs working in the ED during the COVID-19 pandemic. The increase in HE frequency was not associated with the increase in HW frequency, indicating that washing the hands more frequently during the pandemic does not necessarily mean having to endure symptoms more frequently. Although this may be because of the preventive measures used by the HCWs such as hand moisturizer.

Another risk factor for HE is the use of irritant chemicals for the sanitation of the hands for instance alcohol-based hand sanitizers (ABHS). Nevertheless, in a study among 231 HCWs, Lecheheb et al. revealed that $\mathrm{ABHS}$ was well tolerated even among participants with preexisting dermatitis. The study also indicated ABHS was less likely to cause dry skin compared to washing the hands with soap and water (13). ABHS has proven to be effective against the spread of SARS-CoV-2 by dissolving the lipid membrane of the virus as well as denaturing its proteins (14). In consequence, Guertler et al. indicated an increase in hand disinfection among HCWs during the COVID-19 pandemic (7). Our study demonstrates that during the COVID-19 pandemic, the prevalence of the HCWs that use ABHS increased more than a two-fold, while the prevalence of the HCWs that use soap and water for hand sanitation did not change. All in all, HCWs did not renounce to soap and water during the COVID-19 pandemic, but simply added an extra product, which is ABHS.

Various studies indicate that wearing occlusive gloves for a long time increases the risk of developing $\mathrm{HE}(4,5)$. Meanwhile, the glove type is also an important factor that has been associated with HE (15). In our study, we detected that during the COVID-19 pandemic the duration of wearing gloves highly increased. There was a significant increase in latex and vinyl glove usage. This could be simply because latex gloves are the most purchased by the hospitals thus the increase in latex glove usage might support the increase in glove use in general. The increase in vinyl might be due to its simultaneous use with latex gloves to avoid its effect. This conclusion was based upon the answers given by the participants. 
We already know that applying moisturizer on the hands is one of the easiest ways to prevent and treat the hand eczema related symptoms as it is recommended by the American Academy of Dermatology to apply moisturizers either every three to four hours or each time a person washes their hands $(16,17)$. Thus, Guertler et al. indicated an increase in both HW frequency and moisturizer use frequency during the COVID-19 pandemic (7). Erdem et al. concluded that HE was associated with the frequent use of moisturizers (12). Our study compared the frequency of hand moisturizer use before and during the COVID-19 pandemic finding a threefold increase with the beginning of the COVID-19 pandemic. Most of the participants who applied hand moisturizers prior to the COVID-19 pandemic declared applying it before going to bed so they would not have to apply it again. With the increase of the frequencies of $\mathrm{HW}$ and HE during the pandemic, HCWs stated they would apply hand moisturizers mainly during their breaks to prevent washing it off and having to apply it again. Even though it is recommended to apply hand moisturizers each time after washing the hands, HCWs find this recommendation difficult to achieve especially in the ED since they do not have the time between patients to sanitize and then moisturize their hands because they need to attend to the next patient as quickly as possible.
There are some limitations, which should be taken in account when interpreting this study. First of all, an online survey was used to collect data. Therefore, the findings are based only on self-report meaning no clinical exam was performed to diagnose HE. Due to the pandemic and the overwhelmed ED, it was difficult to reach HCWs and convince them to take the time to fill in the survey, which led to a low response rate. Further multicentered studies are required with vaster study population. The association between the frequencies of $\mathrm{HE}, \mathrm{HW}$ and moisturizer apply should be investigated to determine whether hand moisturizer is used as a treatment or a preventive measure.

\section{CONCLUSION}

Hand eczema is a common issue among HCWs, especially with the recommended hand hygiene protocols to prevent the novel coronavirus from spreading. It was demonstrated in our study that HEAS and HW frequency did increase during the pandemic. Since the importance of hand hygiene cannot be overlooked during this battle against COVID-19, it is essential for HCWs to adapt a hand sanitation routine that does not cause or aggravate HE symptoms.

Conflict of Interest: The authors declared no conflict of interest.

\section{References}

1. Liu Y, Ning Z, Chen Y, Guo M, Liu Y, Gali NK, et al. Aerodynamic characteristics and RNA concentration of SARS-CoV-2 aerosol in Wuhan hospitals during COVID-19 outbreak. bioRxiv. doi : 10.1101/2020.03.08.982637

2. who.int WHO/LO interim guidance COVID-19: Occupational health and safety for health workers, (updated 1 April 2020, cited 29 April 2021. Available from: https://www.who.int/docs/default-source/inaugural-whopartners-forum/who-interim-recommendation-on-obligatory-hand-hygiene-against-transmission-of-covid19.pdf

3. Case Report: Handwashing-Induced Dermatitis During the COVID-19 Pandemic. Am Fam Physician. 2020; 102 (6): 327-8.

4. Kampf et al, Prevention of irritant contact dermatitis among health care workers by using evidence based hand hygiene practices:a review, Industrial Health,2007, 45, 645-52.

5. Hamnerius N, Svedman C, Bergendorff O, Björk J, Bruze M, Pontén A. Wet work exposure and hand eczema among healthcare workers: a cross-sectional study. Br J Dermatol. 2018; 178 (2): 452-61.

6. Kiely LF, Moloney E, O'Sullivan G, Eustace JA, Gallagher J, Bourke JF. Irritant contact dermatitis in healthcare workers as a result of the COVID-19 pandemic: a cross-sectional study. Clin Exp Dermatol. 2021; 46 (1): $142-4$.

7. Guertler A, Moellhoff N, Schenck TL, et al. Onset of occupational hand eczema among healthcare workers during the SARS-CoV-2 pandemic: Comparing a single surgical site with a COVID-19 intensive care unit. Contact Dermatitis. 2020; 83 (2): 108-14. 
8. Susitaival P, Flyvholm MA, Meding B, Kanerva L, Lindberg M, Svensson A, Olafsson JH. Nordic Occupational Skin Questionnaire (NOSQ-2002): a new tool for surveying occupational skin diseases and exposure. Contact Dermatitis. 2003 Aug; 49 (2): 70-6.

9. Lan J, Song Z, Miao X, et al. Skin damage among health care workers managing coronavirus disease-2019. J Am Acad Dermatol. 2020; 82 (5):1215-6.

10. Al-Khateeb B. Primary health care and family physicians provide frontline care to the dermatology patients during the era of COVID-19: Recommendations and future directions. J Family Med Prim Care. 2020; 9 (12): 5862-6.

11. Celik V, Ozkars MY. An overlooked risk for healthcare workers amid COVID-19: Occupational hand eczema. North Clin Istanb. 2020;7(6):527-33.

12. Erdem $\mathrm{Y}$, Altunay IK, Aksu Çerman A, et al. The risk of hand eczema in healthcare workers during the COVID-19 pandemic: Do we need specific attention or prevention strategies?. Contact Dermatitis. 2020; 83 (5): 422-3.

13. Ahmed-Lecheheb D, Cunat L, Hartemann P, Hautemanière A. Prospective observational study to assess hand skin condition after application of alcohol-based hand rub solutions. Am J Infect Control. 2012; 40 (2): 160-4.

14. Singh D, Joshi K, Samuel A, Patra J, Mahindroo N. Alcohol-based hand sanitisers as first line of defence against SARS-CoV-2: a review of biology, chemistry and formulations. Epidemiology and Infection. 2020; 148: e229.

15. Hamnerius N, Svedman C, Bergendorff $O$, et al. Hand eczema and occupational contact allergies in healthcare workers with a focus on rubber additives. Contact Dermatitis. 2018; 79 (3): 149-56.

16. Yan $\mathrm{Y}$, Chen $\mathrm{H}$, Chen L, et al. Consensus of Chinese experts on protection of skin and mucous membrane barrier for health-care workers fighting against coronavirus disease 2019. Dermatol Ther. 2020; 33 (4): e13310.

17. Rundle CW, Presley CL, Militello M, et al. Hand hygiene during COVID-19: Recommendations from the American Contact Dermatitis Society. J Am Acad Dermatol. 2020; 83 (6): 1730-7. 